\title{
Rock Magnetic Properties during the Paleocene-Eocene Thermal Maximum (PETM): Records from P/E boundary Sections (Sinjar, Shaqlawa) in Iraq
}

\author{
Ahmed N. Al-Fattah \\ Department of Geology \\ College of Science \\ University of Mosul
}

\author{
Ali I. Al-Juboury \\ Department of Geology \\ College of Science \\ University of Mosul
}

Imad M. Ghafor

Department of Geology

College of Science

University of Sulaimaniya

( Received 22/1/2014 ， Accepted 23/3/2014 )

\begin{abstract}
Rock magnetic properties have been investigated across the Paleocene/Eocene boundary in two distally separate sections of Paleogene marine sedimentary rocks from Iraq, namely the Sinjar and the Shaqlawa sections. The sediments at the studied sections belong to the Aaliji and the Kolosh formations respectively, which were previously examined for their biostratigraphy by the authors using planktonic and benthonic foraminifera to delineate the Paleocene/Eocene (P/E) transition. Measured magnetic properties include; bulk magnetic susceptibility, hysteresis cycles, isothermal remnant magnetization (IRM) acquisition, and thermomagnetic curves analysis. Rock-magnetic results (i.e. low magnetic coercivity component) indicate greigite as the main magnetic phase at Aaliji rocks, while a mixture of magnetite and greigite with high magnetic coercivity has been observed at Kolosh clastics. Magnetic susceptibility is induced by related to both biogenic minerals (mainly at Aaliji Formation) and transported terrigenous material sources. Multi varied magnitude phases of high bulk rock magnetic susceptibility observed in both formations along PETM lithosomes are attributed to two sources: greigite or biogenic iron oxides source and increase in terrigenous discharge source as inferred by anoxic to suboxic iron - sulfate-reducing conditions and lithological change respectively. Both sources referred to some of environmental conditions associated with Paleocene - Eocene thermal maximum events such as methane dissociation, water stratification, enhanced hydrological and weathering cycles.

Keywords: PETM, Magnetostratigraphy, Paleoclimate, Paleocene/Eocene (P/E) boundary, Iraq.
\end{abstract}




\section{الخصائص المغناطيسية الصخريه اثناء فترة التطرف المناخي الحراري الاقسى عبر الباليوسين - الايوسين (PETM) المسجله لمقطعي حد تماس الباليوسين -الايوسين (سنجار و شقلاوه) في العرلق}

$$
\text { قماد محمود غفور علبة العلوم الارض }
$$

$$
\text { قلي اسماعيل الجبوري علوم الارض }
$$

$$
\text { قامع علية العلوم الإضر آل فتاح }
$$

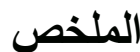

تمت دراسة الخصائص المغناطيسية المميزة عبر فترة التطرف الحراري الاقسى للباليوسين-الايوسين

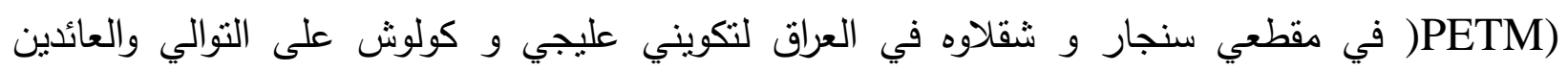
لصخور الباليوجين البحرية والمحددين بالعمر من دراسة سابقه قام بهاب البها الباحثين للفورامنفيرا الطافية والقاعية. شملت الخصائص المغناطيسيه المقاسه مايلي: Bulk magnetic susceptibility, hysteresis) cycles, isothermal remnant magnetization (IRM) acquisition, and thermomagnetic curves analysis). الكركايت كطور مغناطيسي رئيسي في صخور نكوين عليجي في حين كان مزيج من معدني المكنتايت

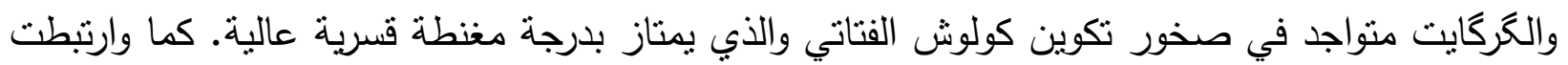

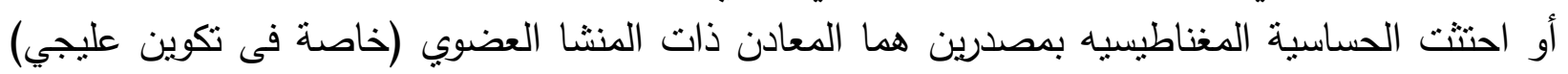

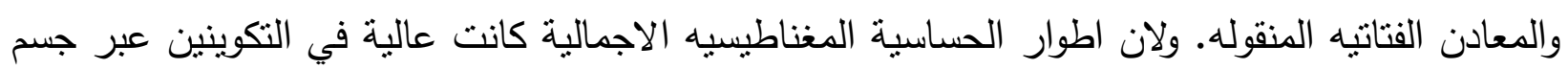

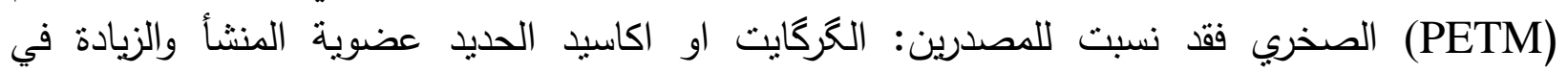

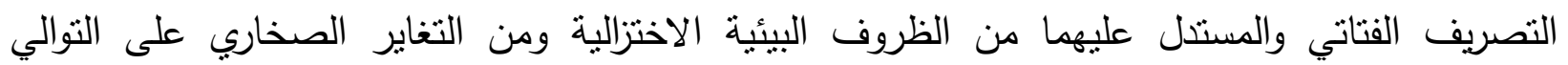

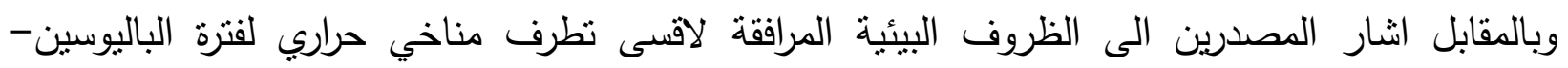

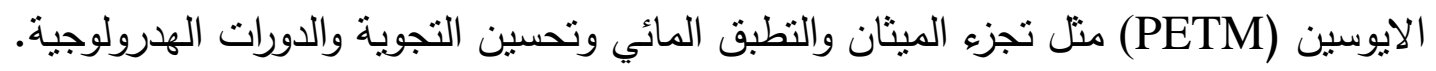

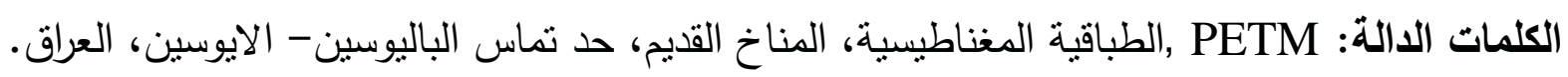

\section{INTRODUCTION}

The Paleocene-Eocene thermal maximum (PETM) was a geologically brief, rapid, abrupt, extreme and peculiar episode of global warming representing significant impact on both marine and terrestrial ecosystem and marked by global temperature rise $\left(5-8{ }^{\circ} \mathrm{C}\right)$ associated with a prominent negative carbon isotope excursion (CIE) $\left(\delta^{13} \mathrm{C}\right)$ (Sluijs et al., 2007). The complete duration of the PETM phenomena is estimated to be approximately ( 170) k.y (Röhl et al., 2007). There were multiple events within the late Paleocene and early Eocene implies a 
unique and non-singular trigger causing the release of huge and catastrophic or chronic fluxes amounts of isotopically light $\mathrm{CO}_{2}$ and/or $\mathrm{CH}_{4}$ into the exogenic (ocean-atmosphere) until generate perturbation in carbon cycle (Sluijs et al., 2007).

Bowen et al. (2006) considered that rapid and extreme changes in the earth system may be triggered by natural carbon cycle perturbation even in times of globally warm climate and in an ice-free world and the PETM phenomena was the obvious indicator of that perturbation. They mentioned that an array of changes in the atmosphere, geosphere, hydrosphere, and biosphere have been documented during the PETM. An Intensified hydrological cycle is one of these changes that was driven by super greenhouse enhanced weathering and erosion and increased terrigenous input from continents (Giusberti, et al., 2007; Kump et al., 2009).

A possible link between the geomagnetic field and catastrophic climate at PETM was recorded by Lee and Kodama (2009), indicating that magnetic properties of sedimentary rock can be used to determine paleoclimate variations. The influx of terrigeneous materials (with a tiny portion of ferrimagnetic components) into marine environments provide paleoclimatic implications which can be extrapolated through study of magnetic properties (e.g. Hounslow and Maher, 1999; Kissel, et al., 2003).

The environmental changes during the extreme warming of the PETM led to enhanced production and/or preservation of authigenic ferrimagnetic minerals that grow as a precursor to pyrite during early diagenetic sedimentary sulfate reduction. In this paper, we present a study of bulk rock magnetic properties across the PETM interval lithesome of two sections located western and northern Iraq. These sections are examined using planktonic foraminifera (Aaliji Formation) and benthonic foraminifera (Kolosh Formation) to determine Paleocene-Eocene boundary (Al-Fattah, 2014). The P/E boundary can easily be delineated by the sudden extinction of specific Taxa. This extinction has been correlated with the onset of the PETM worldwide (Kennett and Stott, 1991; Thomas, 1998). In the studied sections, the PETM event is identified by excursion taxa in the early Eocene such as Acarinina sibaiyaensis at Aaliji Formation and Nuttallides truempyi at Kolosh Formation, (Fig. 1). The current study is the first in Iraq that used rock magnetic tools aiming to give information about the environmental perturbation during PETM climatic event. 

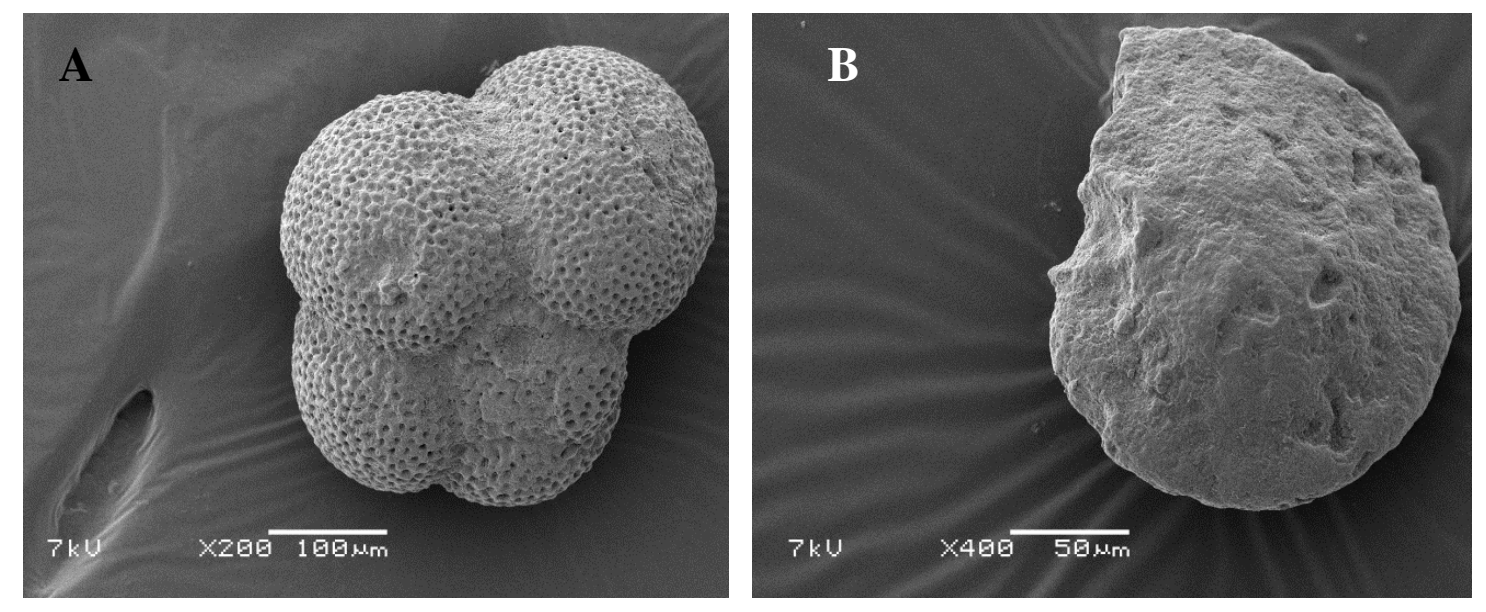

Fig. 1: SEM photo, A-Acarinina sibaiyaensis, dorsally view, B-Nuttallides truempyi, ventral view, Early Eocene, (E1) Biozone excursion taxa.

\section{METHODS AND LITHOLOGY}

A total of 42 not oriented samples spanning PETM lithosomes (21 from each of the Aaliji and Kolosh sections) were selected for rock-magnetic analyses. In the Aaliji Formation, the studied succession is composed mostly of marly limestones, marlstones, and calcareous shales, while in the Kolosh Formation; the studied succession is composed generally of alternating of calcareous shales with silty marls and some limestone beds, (Fig. 2).

All the specimens were weighed and the initial magnetic susceptibility was measured with a $K L Y$ - 2 Kappabridge. In order to determine the nature of the rockmagnetic particles, a selected suite of 5 specimens per each section were analyzed by means of stepwise isothermal remanent magnetization acquisition (IRM) curves up to $2.4 \mathrm{~T}$, imparted with a MMPM 10 Pulse Magnetizer. The value of the magnetization after each of the 26 steps was measured with a 2 G DC SQUID cryogenic magnetometer placed in a magnetically shielded room. The IRM curves were unmixed using the cumulative log-Gaussian (CLG) analysis of Kruiver et al. (2001). A backfield IRM magnetization was then imparted with a field of $0.15 \mathrm{~T}$ (IRM- 0.15T). The IRM at $2.4 \mathrm{~T}$ (saturation isothermal remanent magnetization (SIRM)) and the IRM-0.15T are used to calculate the S-0.15T ratio of Boemendal et al., (1992) by the formula [(-IRM-0.1T/SIRM) +1]/2. The same suite of 10 specimens was subjected to hysteresis loops determination up to a field of $500 \mathrm{mT}$. Values of saturation magnetization (Ms), saturation remanence (Mrs), and coercivity $(\mathrm{Bc})$ were determined from the loops after correcting for a paramagnetic component observed in all specimens. The coercivity of remanence (Bcr) was estimated and calculating the median destructive field of the difference between the ascending (0-500 mT) and the descending (500-0 mT) loop (Tauxe, 2010). 


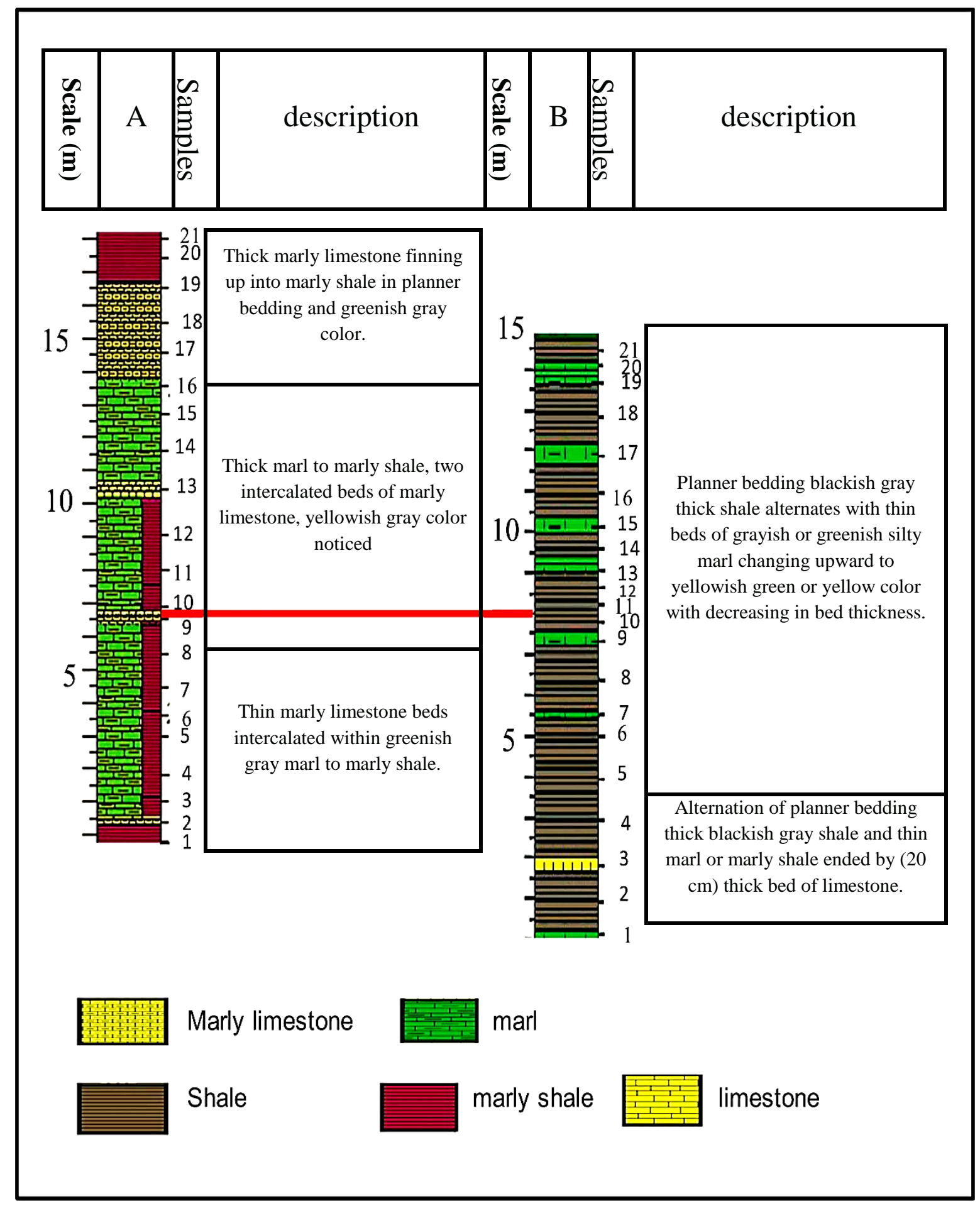

Fig. 2: Lithological description of PETM lithosomes of A: Aaliji Formation and B: Kolosh Formation, thick red line represents Paleocene- Eocene boundary according to Al-Fattah (2014).

Hysteresis analyses were followed by thermomagnetic curve analysis obtained by heating the specimens in air up to a temperature of $650{ }^{\circ} \mathrm{C}$ (demagnetization). The Curie temperatures of the magnetic phases were determined by analysis of second derivative of the curves Tauxe, (2010). 
Hysteresis and thermomagnetic analyses were conducted using a variable field translation balance VFTB; (Krasa et al., 2007), and the data analyses were made with the RockMagAnalyzer 1.0 software of Leonhardt (2006). To evaluate the stratigraphic variations of the magnetic mineralogy across the sections, the S-0.15T ratio of the remaining specimens are also calculated after measuring the SIRM at $2.4 \mathrm{~T}$ and the IRM-0.15T as described above. Analyses were done at paleomagnetic laboratory of Ludwig Maximilians University Munchen, Germany by laboratory technicians.

\section{GEOLOGICAL SETTING}

The middle Paleocene-Eocene megasequence (Arabian Plate Megasequence AP10 according to Sharland et al. (2001) was deposited during a period of renewed subduction and volcanic activity associated with final closure of the NeoTethys. The products of this subduction in Iraq are volcanics of the Walash group (island arc setting) and the clastic-dominated Naopurdan group (forearc setting) (Jassim and Buday, 2006). Recent studies carried out by Ali et al. (2013) and Aswad et al. (2013) show that the Walash-Naopurdan upper volcanic suites display an incredibly broad tectonic setting with long time span ( $19 \mathrm{Ma})$, (Fig. 3). The sedimentary associates with the studied upper volcanic suits are of Lutetial biostratigraphic age (42.5 - $48 \mathrm{Ma}$ ) (Al-Banna and Al-Metwali, 2008). The PETM event, however, was associated with lower volcanic and WalashNaopurdan. Based on the classification scheme of Jassim et al., (2006), the lower volcanic suites are associated with terrigenous sediments. The absence of carbonates in lower volcanic is attributed to shallowing of the Calcite Compensation depth (CCD) due to PETM event. The subduction led to strong uplift along the northeastern margin of the Arabian plate late Cretaceous foreland basin with the formation of ridges and basins generally with a NW-SE trend in north and central Iraq (Mesopotamian basin), and an EW trend in western Iraq.

A new depocenter formed to the southwest within Paleogene Mesopotamian basin which is bordered by carbonate shelves in both sides. Significant lateral facies changes occurred across these tectonic features. Uplift of the eastern Arabian plate margin during early Paleocene explains the absence of Danian sediments from most of high folded zone and foothill zone (Jassim and Buday, 2006; Aqrawi, et al., 2010). Two separate longitudinal basins developed during mid-Paleocene-early Eocene within the unstable shelf. The first interamountain basin (red bed basin) overlies a thrust belt that had been emplaced during late Cretaceous. The second was the Kolosh narrow basin occupying a high folded zone, partly isolated from red bed basin by a NW-SE ridge, and passing into the open marine deep basin that covered most of the foothill zone and the northeast parts of the Mesopotamian zone where Aaliji Formation was deposited (Jassim and Buday, 2006).

The tectonic interruption of the Tertiary flysch basin and its shallowing and migration southwest ward away from the oceanic belt might suggest a transition 
from a remnant oceanic basin into a peripheral foreland basin. The shelf carbonates which characterize the upper parts of the Kolosh Formation at many localities mark the ultimate shoaling of the basin and a period of calming tectonism (Al-Qayim,1993; Al-Sakry, 2006). Due to structural loading and secondary contribution from sediment load, high subsidence rats occur in inherited foreland basins (Sharland, et al., 2001).

Two sections were selected for study in the northern region of Iraq between latitude $\left(36-37^{\circ}\right) \mathrm{N}$. These sections are Sinjar or named Aaliji (northern limb of Sinjar anticline near Zerwa Village) (36 $\left.24^{\prime} 58.53^{\prime \prime} \mathrm{N}, 41^{\circ} 59^{\prime} 9.09^{\prime \prime} \mathrm{E}\right)$, and Kolosh (northern limb of Sephin anticline near Shaqlawa city) $\left(36^{\circ} 24^{\prime} 25.07^{\prime \prime} \mathrm{N}\right.$,

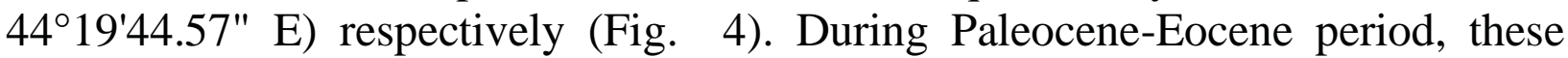
areas were located in Tethys marine environments realm between paleolatitude $\left(25-30^{\circ}\right)$ N, (Scheibner and Speijer, 2008). Tectonically, according to Jassim and Buday (2006) the Kolosh area is located in the high folded zone whereas the Sinjar area lies in the foothill zone (Hemrin -Makhul subzone).

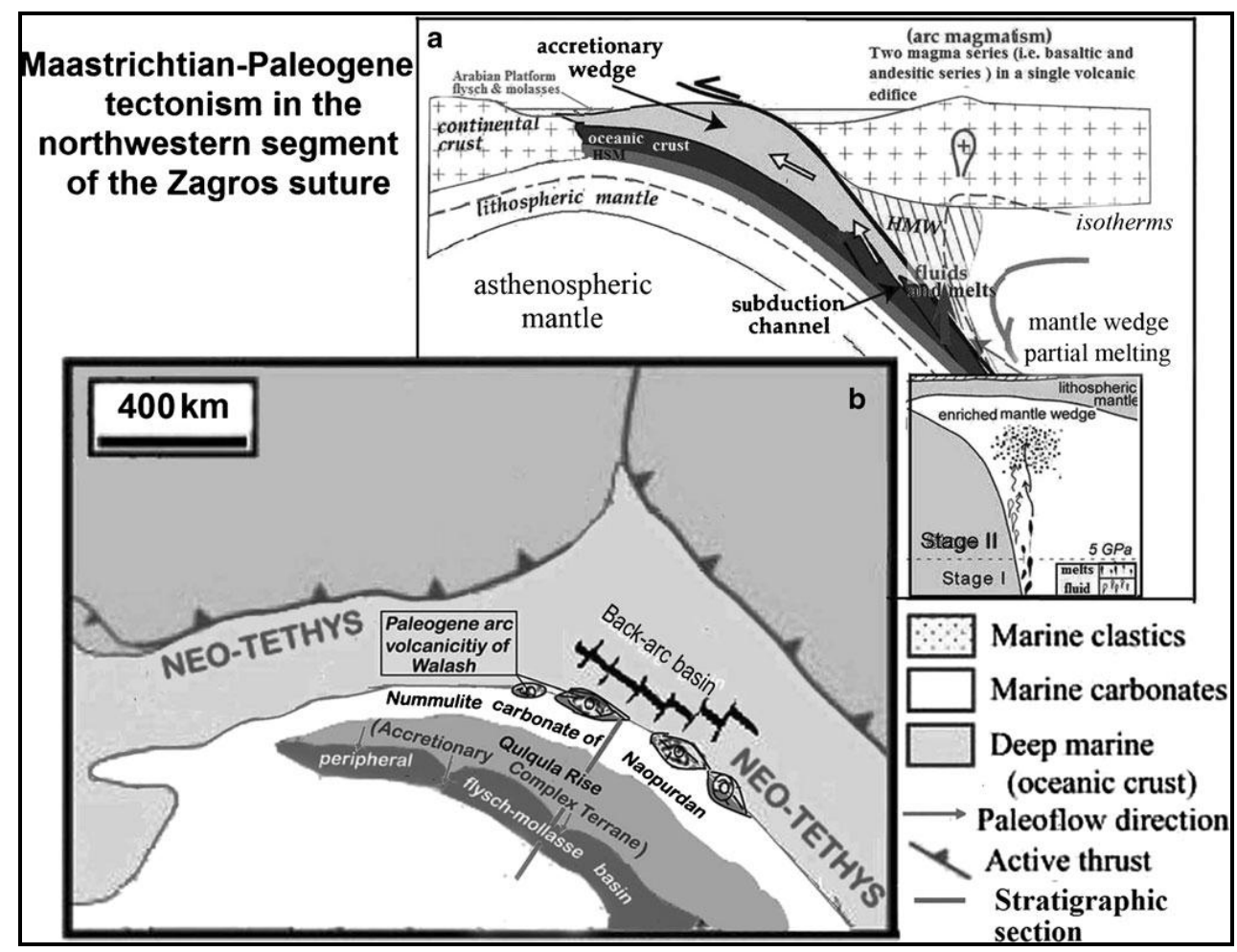

Fig. 3: a- Diagrammatic cross-section of the Maastrichtian-Paleogene tectonism in the northwestern segment of the Zagros suture illustrating the setting and probable origin of Walash volcanites. HSM high serpentinite mantle, HMW high partially melted mantle wedge. b- Simplified palaeogeographic reconstruction for the NeoTethys during Maastrichtian-Palaeogene time (c. 65-32 Ma) after Aswad et al., (2013). 


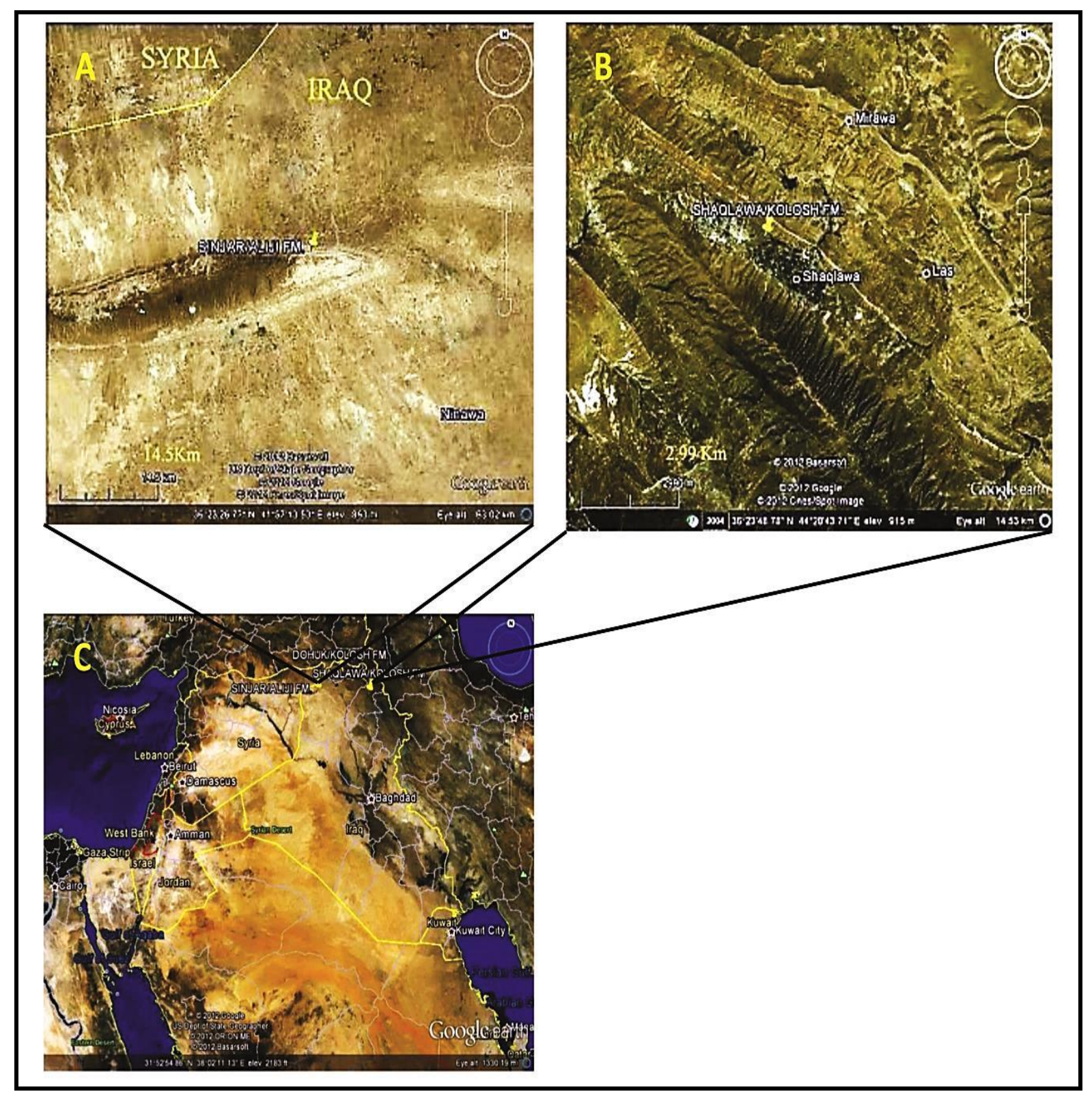

Fig. 4: Google earth pictures showing studied areas locations: A: Aaliji Formation (Sinjar section), B: Kolosh Formation (Shaqlawa section), C: regional location map of Iraq.

\section{RESULTS}

\section{Aaliji PETM lithosome.}

Magnetic susceptibility ranges from 1.6 to $6.1 \times 10^{-8} \mathrm{~m}^{3} \mathrm{~kg}^{-1}$, with an average value of $3.2 \times 10^{-8} \mathrm{~m}^{3} \mathrm{~kg}^{-1}$ (Fig. 5). The CLG (Cumulative log - Gaussian) curves (Fig. 6) show that the specimens are dominated by a low coercivity magnetic phase characterized with a mean $\mathrm{B}_{1 / 2}$ value (the field at which half of the saturation magnetization is reached) of $69-76 \mathrm{mT}$. A minor (1-10\% of the SIRM) high magnetic coercivity phase has also been observed in these specimens. This 
component does not reach saturation and the estimated $\mathrm{B}_{1 / 2}$ is $>2.3 \mathrm{~T}$. Thermomagnetic curves are characterized by a low initial remagnetization that declines during heating down to a minimum at $\sim 400{ }^{\circ} \mathrm{C}$. This minimum is followed by an increase of magnetization that peaks at $\sim 500{ }^{\circ} \mathrm{C}$ and decays completely at an average temperature of $565{ }^{\circ} \mathrm{C}$, approximately the Curie temperature of magnetite. All the cooling curves show a magnetization back at room temperature that is up to 10 times greater than the initial magnetization. When the high coercivity component is more evident the Curie temperature calculated on the cooling curve is up to $30{ }^{\circ} \mathrm{C}$ higher (specimens a5, a14, and a18). The low signal-to-noise ratio that characterizes the hysteresis of the specimens from the Aaliji section does not allow determining reliable hysteresis parameters.

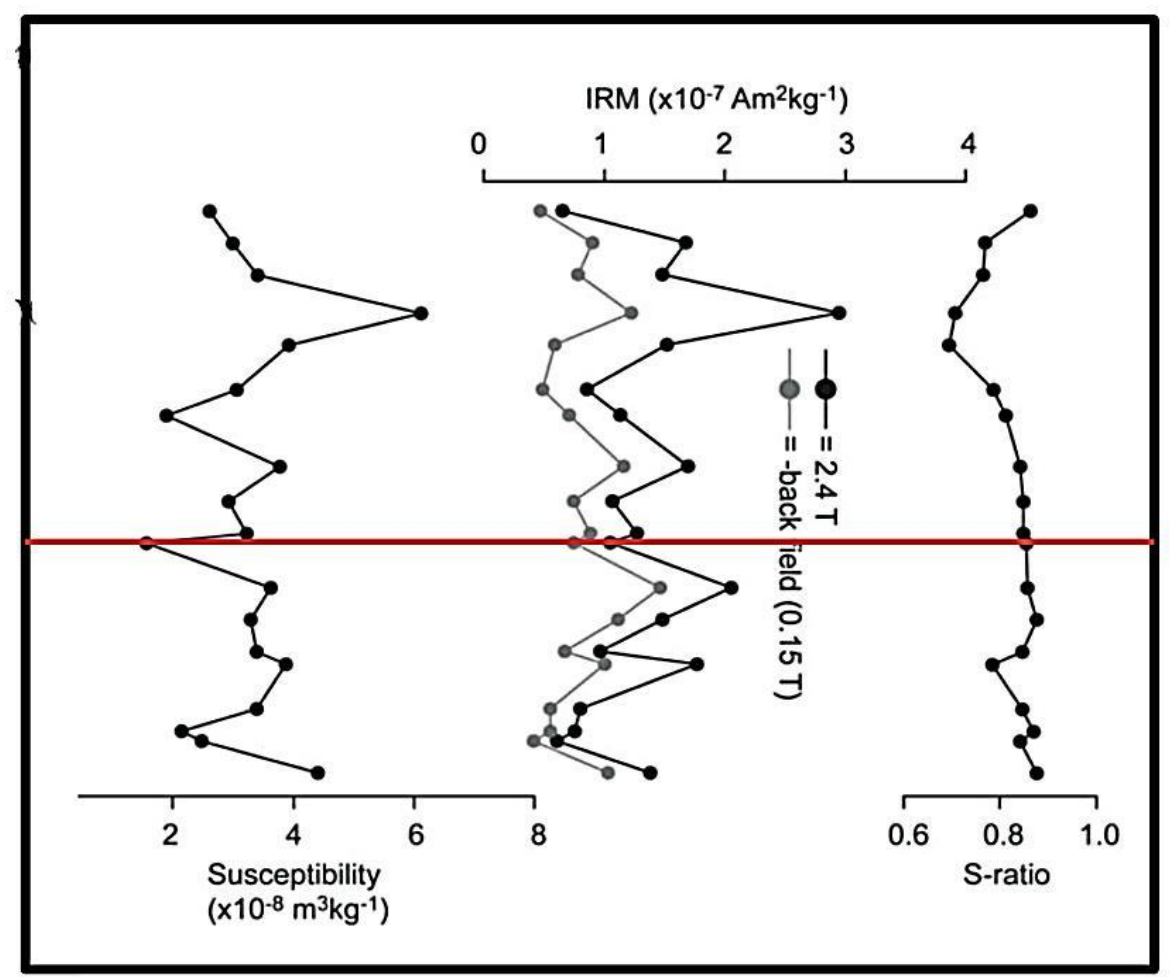

Fig. 5: Magnetic properties across the Aaliji PETM lithesome. From left to right: initial magnetic susceptibility; isothermal remanent acquisition (IRM) imparted with a $2.4 \mathrm{~T}$ field and with a $0.15 \mathrm{~T}$ backfield. IRM- $0.15 \mathrm{~T}$ is expressed as absolute values; S-0.15T ratio, see text for details. Red line corresponds to Paleocene /Eocene contact. 

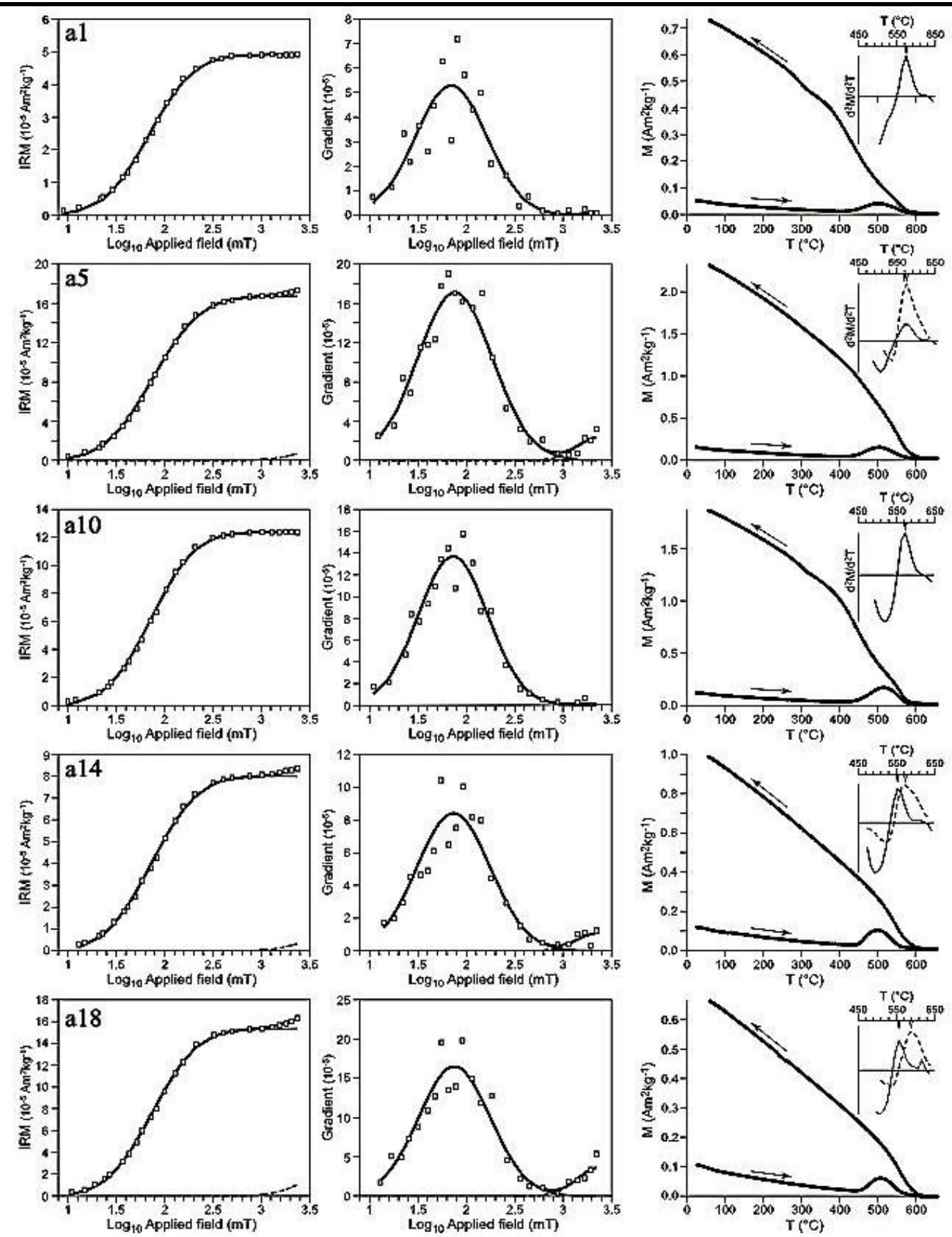

Fig. 6: Cumulative log-Gaussian (CLG) analyses of the IRM stepwise acquisition curves associated with the thermomagnetic curves of five representative specimens from the Aaliji section. From left to right: linear acquisition plots, gradient acquisition plots and thermomagnetic curves. In the CLG plots, the open squares represent IRM data, the thin solid and dashed lines represent, respectively, the low and the high magnetic coercivity components, the sum of which is represented by the thick solid line interpolating the squares. The insets in the thermomagnetic curves are the second derivative of heating curve (solid line) and the cooling curve (dashed line), calculated between 450 and $650{ }^{\circ} \mathrm{C}$ and used to determine the Curie temperatures; see text for details. 
The low coercivity component is interpreted as early diagenetic (bacterial) SP and /or SD greigite $\left(\mathrm{Fe}_{3} \mathrm{~S}_{4}\right)$, which is overgrown either within microenvironments associated with foraminifera shells (Fig. 7) or dispersed in the sediment matrix (Larrasoaña et al., 2007; Dong et al.,2013); in particular, the thermomagnetic curves have the typical behavior observed in greigite bearing sediments described by e.g. Roberts et al. (2011). The greigite magnetic properties are controlled by magnetocrystalline anisotropy, that it is thermally unstable at elevated temperatures (thermal instability precluded determination of the Curie temperature (Tc), which must lie above $322^{\circ} \mathrm{C}$ ), and that, unlike magnetite, it undergoes no crystallographic or magnetic transition when cooled to low temperatures. The increase of magnetization observed around $500{ }^{\circ} \mathrm{C}$ is due to the greigite-magnetite phase transformation during heating in air, which also results in higher magnetization during cooling (Zheng et al., 2010).

The minor non-saturating coercivity phase is interpreted as goethite, which possesses a coercivity that can be 10's of teslas (Tauxe, 2010). This goethite phase turns to hematite during heating (usually at around $250-400{ }^{\circ} \mathrm{C}$ ), making the Curie temperatures of the cooling cycles higher than those observed during heating, as particularly evident in specimens a5, a14, and a18 of (Fig. 6). The absolute values of the SIRM and the IRM ${ }_{-0.15 T}$ range from 0.35 to $6.90 \times 10^{-7} \mathrm{Am}^{2} \mathrm{~kg}^{-1}$ and the derived $S_{-0.15 T}$ ratio has an average value of 0.8 , which does not show evident variation across the section, indicating that the sediments are generally dominated by the same relative amount of low coercivity greigite (Fig. 5).
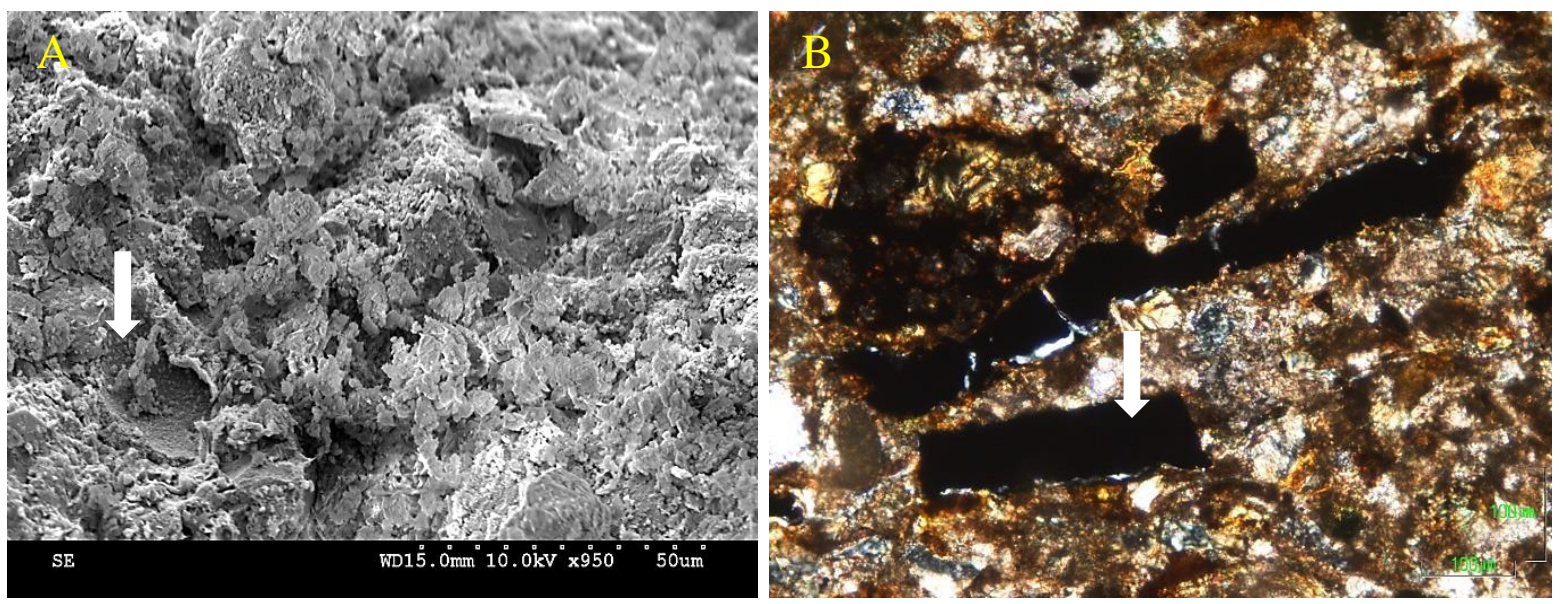

Fig.7: A- SEM photo showing greigite $\left(\mathrm{Fe}_{3} \mathrm{~S}_{4}\right)$ overgrown within Microenvironments Associated with Foraminifera shell (Arrow), B- Elongated Chain of Biogenic or Bacterial Fe-Bearing Minerals (Magnetosomes) (Arrow). 


\section{Kolosh PETM lithosome.}

The initial magnetic susceptibility ranges from 0.03 to $2.6 \times 10^{-7} \mathrm{~m}^{3} \mathrm{~kg}^{-1}$, with the highest values from 2 to $9 \mathrm{~m}$, where the Paleocene/Eocene boundary is located (Fig. 8). The CLG and the thermomagnetic curves suggest the presence of magnetite in the specimens coexisting with minor greigite (Fig. 9). In addition, the hysteresis loops (Fig. 10). The SIRM and the IRM-0.15T vary across the section following the magnetic susceptibility, reaching a peak value of $2.8 \times 10^{-5} \mathrm{Am}^{2} \mathrm{~kg}^{-1}$ at about $3 \mathrm{~m}$, decreasing to $0.02 \times 10^{-5} \mathrm{Am}^{2} \mathrm{~kg}^{-1}$ just above the Paleocene/Eocene boundary at $9 \mathrm{~m}$, with a rise of values at the top of the sampled section. These variations are not observed in the $S_{-0.15 T}$ ratio, which shows constant values of $\sim 0.9$ across all the section, indicating no variations in the magnetic coercivity phases of the sediments.

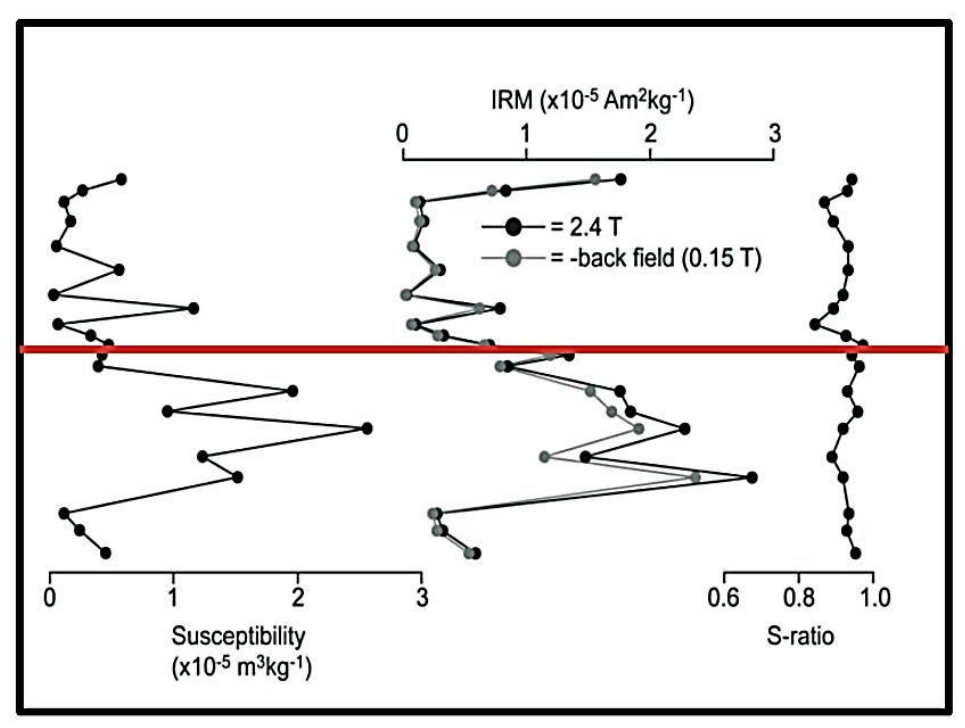

Fig. 8: Magnetic properties across the Kolosh section. From left to right: initial magnetic susceptibility; isothermal remanent acquisition (IRM) imparted with a $2.4 \mathrm{~T}$ field and with a $0.15 \mathrm{~T}$ backfield. IRM-0.15T is expressed as absolute values; S-0.15T ratio, see text for details. Red line corresponds to Paleocene/Eocene boundary. 


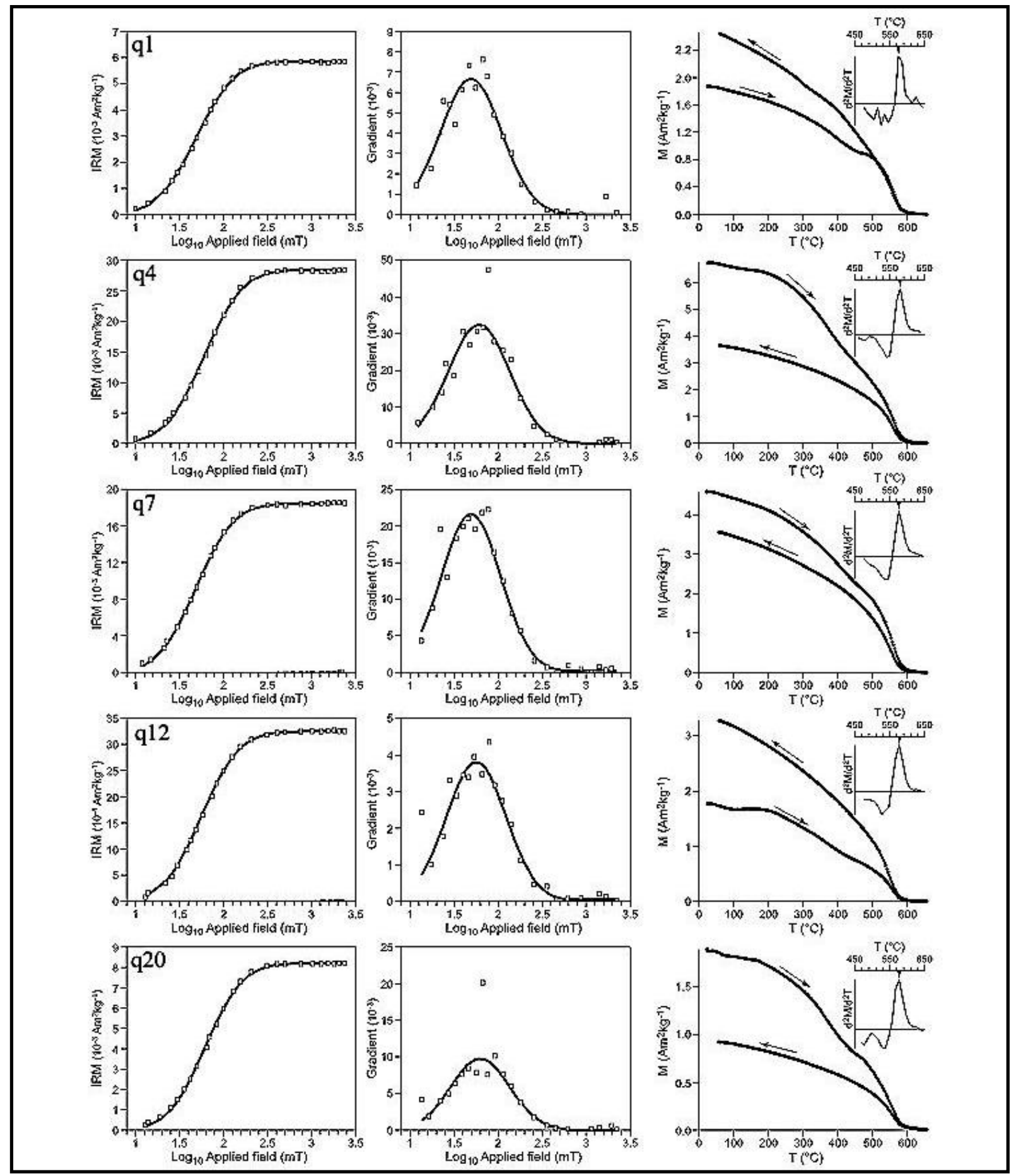

Fig. 9: CLG analyses of the IRM stepwise acquisition curves associated with the thermomagnetic curves of five representative specimens from the Kolosh section. From left to right: linear acquisition plots, gradient acquisition plots and thermomagnetic curves. In the CLG plots, the open squares represent IRM data, the thin solid and dashed lines represent, respectively, the low and the high magnetic coercivity components, the sum of which is represented by the thick solid line interpolating the squares. The insets in the thermomagnetic curves are the second derivative of heating curve, calculated between 450 and $650{ }^{\circ} \mathrm{C}$ and used to determine the Curie temperature; see text for details. 


\section{DISUSSION}

\section{Paramagnetic vs. ferromagnetic contributions}

Several arguments point to a strong control of the susceptibility signal in the studied sections by ferromagnetic content. First, the two sections shows vary values of susceptibility, while SIRM is similar magnitude with the IRM ${ }_{0.15 \mathrm{~T}}$. This indicates that the contribution of the ferromagnetic fraction to the total susceptibility must be large comparing to lesser contribution of paramagnetic fraction. Second, the clear increases in susceptibility observed in both sections are correlated with an equally significant increase in SIRM ( Figs. 5 and 8). Third, the hysteresis cycles of selected samples are showed S-shaped (nonlinear) trends (Fig. 10) (Villasante-Marcos et al, 2009). The PETM sequence may be characterized by the sedimentary replacement of diamagnetic ooze by ferromagnetic grains and paramagnetic clays. This replacement continued after the rapid shoaling of both lysocline and calcium compensation depth followed by the neutralization of lowered $\mathrm{pH}$ in the deep sea floor (Zachos et al., 2005).

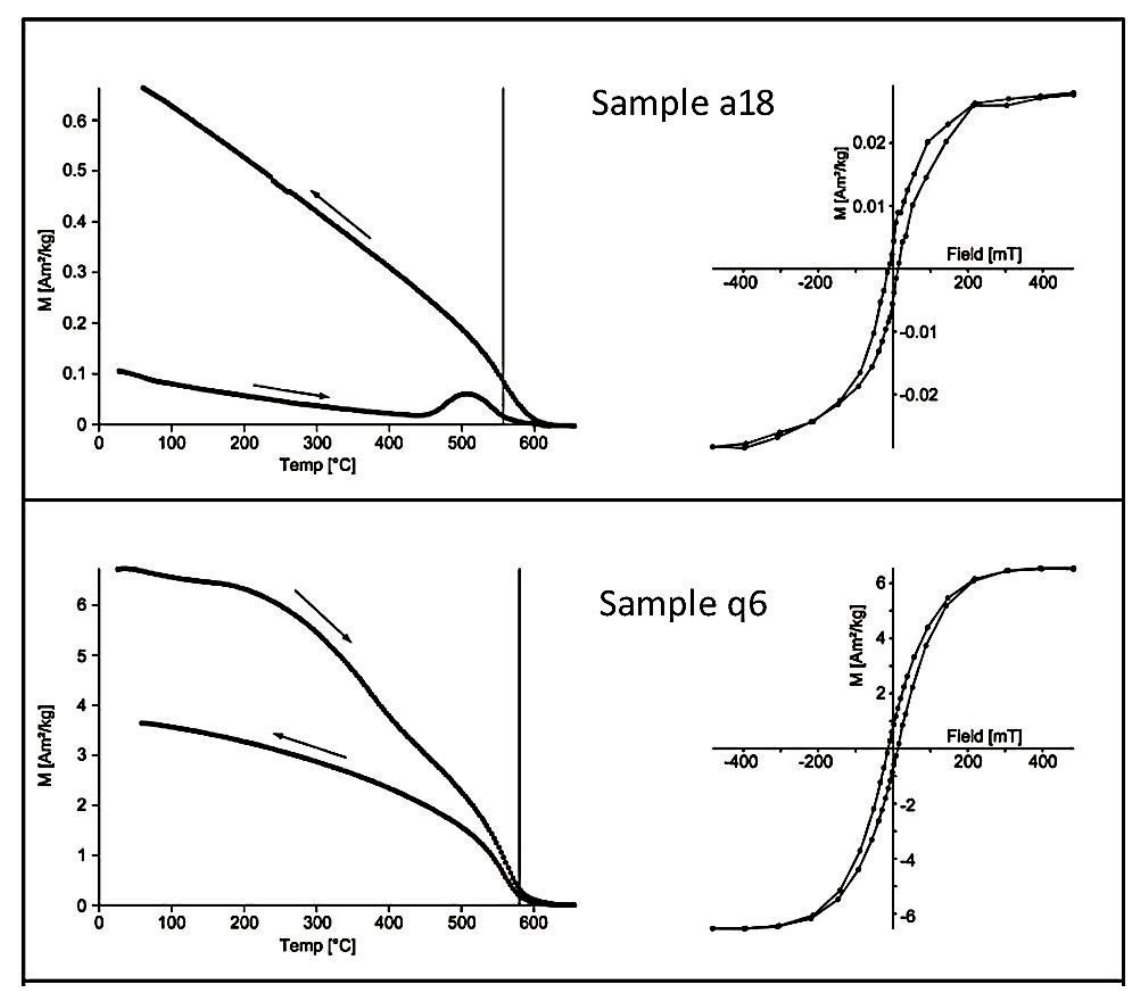

Fig.10: Thermomagnetic Curves and Hysteresis Loops from Two Representative Specimens from the Aaliji and the Kolosh Sections, Corrected for the Paramagnetic Components, $\mathrm{M}=$ Magnetization. 


\section{MAGNETIC SUSCEPTIBILITY}

Magnetic susceptibility is generally very low at two sections. There is multiphases increase in bulk magnetic susceptibility at both lithosomes. At Aaliji Formation (in upper Paleocene then progressively within two phase in early Eocene), and relatively around $\mathrm{P} / \mathrm{E}$ at Kolosh Formation also (high in upper Paleocene then decrease with lesser phase at onset of early Eocene and reback upward to another expected peak). Considering prevailed anoxic and euxnic or reducing environmental conditions within PETM intervals of both Aaliji and Kolosh formations as well as confirmation of biogenic or bacterial contribution (magnetosomes) to produce iron oxides (Al-Fattah, 2014) (Fig. 7,B), the general increase in magnetic susceptibility can be attributed to biogenic or bacterial Fe-bearing minerals contribution (magnetosomes), as previously described by Villasante-Marcos et al. (2009) in New Zealand. Nevertheless, this increase may also be consistent with amounts of detrital material, as expected from the change in lithology from limestone to marl and / or marly shale in Aaliji and from limestone to shale /marl couplets in Kolosh section.

Authigenic greigite and /or pyrrhotite formed as a byproduct of the anaerobic oxidation of methane (AOM), and the methanic/gas hydrate zones. Thus, the rock magnetic identification of greigite $\left(\mathrm{Fe}_{3} \mathrm{~S}_{4}\right)$ and monoclinic pyrrhotite $\left(\mathrm{Fe}_{7} \mathrm{~S}_{8}\right)$ should be useful marker for the detecting ancient gas hydrate systems in the marine sedimentary record, where methane and disseminated gas hydrates as sedimentation continues and/or as pressure and temperature conditions change might have occurred. (Housen and Musgrave, 1996; Musgrave et al., 2006). Dissociation of gas hydrates might have played a prominent role in driving global climate change, which means that the greigite identification in itself is a good indication for PETM (Larrasoaña et al., 2007). On the other hand, the abundance and character of bacterial magnetite and/or greigite can reflect environmental chemical stratification of sediments and the water column as a one of environmental responds to PETM (Kopp and Kirschvink, 2008).

An increase in magnetic susceptibility may refer to relatively increase in terrigenous discharge as evidenced by lithological changes and probably signifies an acceleration of the hydrological and weathering cycles, which were considered as another environmental responds of PETM event (Villasante-Marcos et al., 2009; Storme et al., 2012). Finally, a drop in magnetic susceptibility may represent both enhanced carbonate accumulation versus siliciclastic delivery.

Due to increase in magnetic susceptibility in the studied sections relates to the abundance of ferromagnetic minerals, which typically corresponds to the amount of biogenic and/or diagenetic origin (magnetosomes), with paramagnetic minerals contribution which are correspond to the amount of detrital material in marine sediment. Therefore, magnetic susceptibility is induced by or related with two sources, biogenic minerals (mainly at Aaliji Formation) and transported 
terrigenous materials and both sources referred confidently to some of prevailed environmental factors during PETM.

\section{Saturation Isothermal Remanent Magnetization (SIRM)}

SIRM (the remanent magnetization acquired by the sample under the maximum applied magnetic field of $2.4 \mathrm{~T}$ ) (Villasante-Marcos et al, 2009). The SIRM directly relates to the ferromagnetic content of the sediment. The most increases in susceptibility are very similar in magnitude and coincided with increases in SIRM and thus in ferromagnetic content. These parameters are more obvious in Aaliji section than Kolosh section, which are indicating again that the ferromagnetic versus paramagnetic contribution to the magnetic properties is higher especially at Aaliji section; and that the susceptibility increase within the PETM lithosomes are mainly controlled by ferromagnetic fraction in addition to extra paramagnetic fraction, as a terrigenous fraction especially at Kolosh section. The alternating relative increases in SIRM associated Aaliji and Kolosh formations with relative increases in both the ferromagnetic content can be explained by variable terrigenous input, with sporadic intensification of discharge fluxes. The weathered terrigenous material largely composed of mixture of different ferromagnetic fraction, and has some paramagnetic minerals (i.e. clays in shale or marl).

\section{COERCIVITY OF REMANENCE}

Coercivity of remanence (the point where the back demagnetization IRM curve intersects the $\mathrm{x}$-axis, corresponding to the back magnetic field that has to be applied to eliminate the SIRM acquired previously) (Villasante - Marcos et al, 2009).

The low coercivity component at Aaliji is interpreted as greigite, with minor contributions of non-saturating coercivity phase is interpreted as goethite, whereas, at Kolosh section magnetite as a high coercivity coexisting with minor greigite as a low coercivity component. The extent of authigenic formation of fine - grained greigite is linked to enhanced sulphidic conditions, whereas goethite are largely unaffected by this reductive conditions because aluminous goethite can survive in the relatively enhanced sulphidic environments. Nevertheless, low or small variations in goethite contents indicate accumulation under minor aeolian dust inputs and within wet phases, in response to an intensified African monsoon (Liu et al, 2012) The coercivity of remanence is an indicator of the possible presence of ferromagnetic mineral, while the high-field susceptibility represents composite values of ferromagnetic and paramagnetic minerals ( Lee and Kodama, 2009). 


\section{CONCLUSION}

1- The susceptibility signal in the studied sections controlled by ferromagnetic content especially at the Aaliji Formation and relatively with sharing of paramagnetic contents at the Kolosh Formation

2-Magnetic susceptibility along PETM lithosomes is related to two sources: biogenic minerals source (mainly at the Aaliji Formation) and transported terrigenous materials source.

3- The rock magnetic identification of greigite is a useful marker for the detecting ancient gas hydrate systems in the marine sedimentary record that might have hosted methane, and can reflect environmental chemical stratification of sediments and the water column.

4-Goethite identification in the Aaliji Formation indicates accumulation under minor aeolian dust inputs and within wet phases.

5-Terrigenous discharge increase is detected by magnetic susceptibilities (especially at the Kolosh Formation) and thus refer indirectly for enhanced hydrological and weathering cycles that is tied with PETM environmental conditions.

6-Both magnetic susceptibility sources and other magnetic parameters are considered as evidence to global climate and environmental perturbation during PETM.

\section{REFERECNES}

Al-Banna, N., Al-Metwali, M., 2008. Microfacies and Age Determination of the Sedimentary Sequences within Walash Volcanosedimentary Series, Mawat nappes, NE Iraq. Tikrit J Pure Sci 13, pp. 308 - 314.

Al-Fattah, A. N. Th. 2014.Environmental Perturbation Associated with PaleoceneEocene Thermal Maximum (PETM) Northern Iraq, Unpublished Ph. D thesis, Mosul University, Iraq.

Ali S.A., Buckman B., Aswad K. J., Jones B. G., Ismail S. 2013. The Tectonic Evolution of a Neo - Tethyan (Eocene-Oligocene) Island arc (Walash Naopurdan Group) in the Kurdistan region of the NE Iraqi Zagros Thrust Zone. Island Arc journal. 22, pp. 104 - 125.

Al-Qayim, B., 1993. Petrofacies Analysis and Tectonic Evolution of Zagroside Flysch Suites from Northeastern Iraq. In: Kumon and Ku (Eds.), Petrology of sandstones in relation to tectonics, V. S. P, Netherlands, pp. 33 - 34.

Al-Sakry, S. I., 2006. Sequence Stratigraphy of the Paleocene-Lower Eocene Succession, Northeastern Iraq, Unpublished Ph.D Thesis, University of Baghdad, $240 \mathrm{p}$.

Aqrawi, A. A. M., Goff, J. C., Horbury, A. D., and Sadooni, F. N., 2010. The Petroleum Geology of Iraq, Scientific Press Ltd, UK, 424 p. 
Aswad, .J. A.; Al-Samman, A. H. M.; Aziz, N. R. H. 2013. The Geochronology and Petrogenesis of Walash Volcanic Rocks, Mawat Nappes: Constraints on the Evolution of the Northwestern Zagros Suture Zone, Kurdistan Region, Iraq. Arabian Journal of Geosciences , 28, pp.1 - 30.

Boemendal, J., King, J.W., Hall, F.R., and Doh, S., 1992. Rock Magnetism of late Neogene and Pleistocene Sediments: Relationship to Sediment Source, Diagenetic Processes, and Sediment lithology, J. Geophys. Res, 97, pp. $4361-4375$.

Bowen, G.J., Bralower, T.J., Delaney, M.L., Dickens, G.R., Kelly, D.C., Koch, P.L., Kump, L. R., Meng, J., Sloan, L.C., Thomas, E., Wing, S.L. and Zachos, J. C., 2006. Eocene Hyperthermal Event Offers Insight into Greenhouse Warming, EOS, Transactions of the American Geophysical Union, Vol. 87, No. 17,pp. 165 - 169.

Dong,J., Zhang, S., Jiang, G., Li, H.,Gao, R., 2013. Greigite from Carbonate Concretions of the Ediacaran Doushantuo Formation in South China and its Environmental Implications, Precambrian Research 225, pp. 77 - 85.

Giusberti, L., Rio, D., Agnini, C., Backman, J., Fornaciari, E., Tateo, F., Oddone, M., 2007. Mode and Tempo of the Paleocene-Eocene Thermal Maximum in an Expanded Section from the Venetian Pre-Alps. GSA Bulletin 119, pp. $391-412$.

Hounslow, M.W., Maher, B.A., 1999. Source of the Climate Signal Recorded by Magnetic Susceptibility Variations in Indian Ocean Sediments. J. Geophys. Res. 104, pp. 5047 - 5016.

Housen, B. A., Musgrave, R. J., 1996. Rock - Magnetic Signature of Gas Hydrates in Accretionary Prism Sediments. Earth Planet. Sci. Lett.139, pp. 509 - 519.

Jassim, S. Z., Buday, T., Cicha, I.,Opletal, M., 2006. Tectonoostratigraphy of the Zagros suture. In Jassim, S. Z., and Goff, J.C.(Eds) Geology of Iraq. Dolin, Prague and Moravian Museum, Brno, Czech Republic. pp. 155 - 167.

Jassim, S. Z., and Buday, T., 2006. Middle Paleocene - Eocene Megasequence (AP 10). In Jassim, S. Z., and Goff, J. C.(Eds) Geology of Iraq. Dolin, Prague and Moravian Museum, Brno, Czech Republic. pp. 155 - 167.

Kennett, J. P., Stott, L. D., 1991. Abrupt Deep-Sea Warming, Palaeoceanographic Changes and Benthic Extinctions at the end of the Palaeocene. Nature 353, pp. 225 - 229.

Kissel, C., Laj, C., Clemens, S., Solheid, P., 2003. Magnetic Signature of Environmental Changes in the last 1.2 Myr at ODP Site 1146, South China Sea. Mar. Geol. 201, pp. 119 - 132.

Kopp, R. E., Kirschvink, J. L., 2008. The Identification and Biogeochemical Interpretation of Fossil Magnetotactic Bacteria. Earth Sci Rev. 86: pp. 42 - 61.

Krása, D., Petersen, K. and Petersen, N. 2007. Variable Field Translation Balance, in: Gubbins, D., and Herrero-Bervera, E. (Eds.), Encyclopedia of Geomagnetism and Paleomagnetism. Springer, pp. 977 - 979. 
Kruiver, P. P., Dekkers, M. J., and Heslop, D., 2001. Quantification of Magnetic Coercivity Components by the Analysis of Acquisition Curves of Isothermal Remanent Magnetisation, 189, pp. 1 - 7.

Kump, L., Bralower, T., Ridgwell, A., 2009. Ocean Acidification in Deep Time.

Oceanography, 22, pp. 94 - 107.

Larrasoaña, J. C., Roberts, A. P., Musgrave, R. J., Gràcia, E., Piñero, E., Vega, M., Martínez - Ruiz,F., 2007. Diagenetic Formation of Greigite and Pyrrhotite in Gas Hydrate Marine Sedimentary Systems, Earth and Planetary Science Letters, 261, pp. 350 - 366.

Lee, Y. S., and Kodama, K., 2009. A possible link between the Geomagnetic Field and Catastrophic Climate at the Paleocene-Eocene Thermal Maximum, Geology, Vol. 37, No. 11, pp. 1047 - 1050.

Leonhardt, R., 2006. Analyzing Rock Magnetic Measurements: The Rock Mag Analyzer 1.0 Software. Computers and Geosciences Vol. 32, pp. $1420-1431$.

Liu, Q., Larrasoaña, J. C., Torrent, J., Roberts, A. P., Rohling, E. J., Liu, Z., Jiang, Z., 2012. New Constraints on Climate Forcing and Variability in the CircumMediterranean Region from Magnetic and Geochemical Observations of Sapropels S1, S5 and S6. Palaeogeography, Palaeoclimatology, Palaeoecology, Vol. 333, No. 334, pp. 1 - 12.

Musgrave, R .J., Bangs, N. K., Larrasoaña, J. C., Gràcia, E., Hollamby, J. A., Vega, M.E., 2006. Rise of the Base of the Gas Hydrate Zone Since the last Glacial Recorded by Rock Magnetism. Geology, 34, pp. 117 - 120.

Roberts, A. P., Chang, L., Rowan, C. J., Horng, C. S., Florindo, F., 2011. Magnetic Properties of Sedimentary Greigite $\left(\mathrm{Fe}_{3} \mathrm{~S}_{4}\right)$ : An Update. Reviews of Geophysics 49, RG1002.

Röhl, U.,Westerhold, T., Bralower, T. J., Zachos, J. C., 2007. On the Duration of the Paleocene-Eocene Thermal Maximum (PETM), Geochemistry, Geophysics, Geosystems, 8, pp. 1 - 13.

Scheibner, C., Speijer, and R. P., 2008. Late Paleocene-Early Eocene Tethyan Carbonate Platform Evolution - Aresponse to long- and Short - Term Paleoclimatic Change. Earth-Science Reviews 90, pp. 71 - 102.

Sharland, P. R., Archer, R., Casey, D. M., Davis, R. B., Hall, S. H., Heward, A. P., Horbury, A. D., and Simmons, M. D.; 2001. Arabian Plate Sequence Stratigraphy. GeoArabia, Special publication, No. 2. 372 p.

Sluijs, A., Bowen, G. J., Brinkhuis, H., Lourens, L. J. and Thomas, E., 2007. The Palaeocene - Eocene Thermal Maximum Super Greenhouse: Biotic and Geochemical Signatures, Age Models and Mechanisms of Global Change. In: M. Williams, et al., (Eds), Deep Time Perspectives on Climate Change: Marrying the Signal from Computer Models and Biological Proxies. The Micropalaeontological Society, Special Publications, The Geological Society, London, pp. 323 - 349. 
Storme, J. Y., Devleeschouwer, X., Schnyder, J., Cambier, G., Baceta, J. I., Pujalte, V., DI Matteo, A., Iacumin, P., Yans, J. 2012. The Paleocene/Eocene Boundary Section at Zumaia (Basque - Cantabric Basin) Revisited New Insights from High Resolution Magnetic Susceptibility and Carbon Isotope Chemostratigraphy on Organic Matter $\left(\delta^{13} \mathrm{Corg}\right)$. Terra Nova, 24, pp. 310 - 317.

Tauxe, L., 2010. Essentials of Paleomagnetism, Univ. California Press, Berkeley, CA., xvi, 489 p.

Thomas, E., 1998. Biogeography of the later Paleocene Benthic Foraminiferal Extinction. In: Aubry, M.-P., Lucas, S.G., Berggren, W.A. (Eds.), Late Paleocene-Early Eocene Climatic and Biotic Events in Marine and Terrestrial Records. Columbia University Press, pp. 214 - 235.

Villasante - Marcos, V., Hollis, C. J., Dickens, G.R., Nicolo, M. J., 2009. Rock Magnetic Properties Across the Paleocene-Eocene Thermal Maximum in Marlborough, New Zealand. Geologica Acta. 7, pp. 229 - 242.

Zachos, J. C. Röhl, U., Schellenberg, S. A., Sluijs, A., Hodell, D. A., Kelly, D. C., Thomas, E., Nicolo, M., Raffi, I., Lourens, L.J., Mc Carren, H. and Kroon, D., 2005, Rapid Acidification of the Ocean During the Paleocene-Eocene Thermal Maximum, Science,VOL. 308, No. (728, pp. 1611 - 1615.

Zheng, Y., Kissel, C., Zheng, H. B., Laj, C., Wang, K., 2010. Sedimentation on the Inner Shelf of the East China Sea: Magnetic Properties, Diagenesis and Paleoclimate Implications, Marine Geology, 268, pp. 34 - 42. 